\title{
PROMOTION OF SELF-CONFIDENCE OF A PROSPECTIVE MUSIC TEACHER AS A PERFORMER
}

\author{
Asta Rauduvaitè \\ Vytautas Magnus University, Lithuania \\ Guanhua Bi \\ Vytautas Magnus University, Lithuania
}

\begin{abstract}
Self-confidence is a key factor that influences stage performance. To form a positive state while performing on the stage, self-confidence becomes the most important aspect, as it is one of the main guarantees of successful performing. However, in music teaching, many students lack self-confidence when performing, which in most cases hinders their performance results. The aim of the study is to reveal the peculiarities of promoting self-confidence of students as performers. A questionnaire and an interview with music education students were used to collect the data. The results of the questionnaire allow concluding that experience as a performer, physical and psychological preparation, and self-regulation are the three major factors influencing students' lack of confidence during the performance. Additionally, the responses from the interview indicated other equally prominent and influential factors such as performing environment, practice level and stage experience. Lastly, the interviewed students proposed ways to boost self-confidence, which include gaining more music knowledge and improving their music skills, practicing harder and applying self-regulation.
\end{abstract}

Keywords: music education, performance, self-confidence.

\section{Introduction}

Globalisation, digital technology development, considerable changes in social life, an increasing flow of information, invasion of massive culture into all the spheres of personal life have also had an influence on musical culture, the process of music education, professional activity of music teacher and teacher education in general.

The choice of the profession of music teacher is a relevant and complex process, which has influence of the whole life of a person. As it is well-known, young people encounter rather serious challenges making endeavour to find their solid place in the professional world of adults. Therefore acquisition of competences, learning, professional development make up important prerequisites for a young individual, who is eager to plan her/his own professional path. On the other hand, one's career does not necessarily have to be an outcome 
of learning, competence acquisition and professional development. This also requires an active personal position and development of self-confidence. Successful professional activity of a teacher is predetermined by the individual's self-expression and compliance between the profession and personal interests or hobbies (Kirkpatrick \& Mortimer, 2002). The successful professional expression of music teacher is closely interrelated with creating states on stage and on abilities to develop self-confidence.

According to X. Li (2014), as soon as an individual steps onto the stage, she or he must have the confidence because self-confidence is the prerequisite and foundation for success. Music education is an important part of art education, as it develops students' mental abilities and personality, evokes the pursuit of good things and inspires people to gain and share experience. However, sometimes it is not possible to achieve this due to the lack of self-confidence. R. Kirliauskiene (2018) confirms that for some personality types, emotional stress helps to mobilise their spiritual power, whereas others can change unrecognizably: a person may become tense, confused, the colour of her/his skin may change, hands may start trembling, which makes it hardly possible to perform in the best possible way. The profession of music teacher may also be regarded as a profession of increased emotional stress because one essential component - concert activity naturally forms different degrees of psychological stress.

Music performance anxiety (MPA) affects mental states of amateurs, students and professional musicians (Paliaukienè, 2018; Constantin, 2017), as the goal of any musician is to achieve excellency in interpretation of a musical composition, in order to receive public's appreciation of his or her performance. Mental training can open the door to performer's inner creative energy flow that is concealed behind restricted patterns. Mental training exercises bring energy that can be canalized into the music and strengthen music performance, memory, creativity, attention and self-confidence. These exercises help to deal with stress and accumulation of adrenalin from traumatic performance experiences.

According to V. Kiik-Salupere (2013), the contemporary vocal pedagogy needs to deal with two major tasks: developing vocal skills of a student and increasing her/his awareness about how to cope with competitive environment and other possibly stressful situations during performance. These two issues are closely entwined and interdependent. The singing voice is a part of a person who is to "play upon it", and therefore the psychological state of a singer can have the most profound and direct effect on the quality of the emerging sound. The study revealed some factors of concern to singing students of all groups: keeping the voice in good condition, memorizing lyrics and making a good impression during actual performance. Factors having a negative effect on singing were as follows: bad mood, unfavourable conditions and being in a hurry. 
Furthermore, H. Spielman (2009) states that a crucial factor for development of self-confidence is the practice of positive thinking, which is also an important factor which helps with performing under pressure. She adds that it is not advisable to expect perfection because live performance always brings risks. The ability to respond to the interpretive elements of the composition in order to express its emotional character means going beyond correctness. This is a precious skill and when a performer has it, it is immediately noticeable to any listener. Traditional teaching has not always excelled in this area. Describing emotional importance to students, even with the most compelling words, does not necessarily help them to make authentic connections. The ability to conceptualize and transfer musical ideas defines the perfect students.

According to A. Kruglanski (2000), individual vocal expression in music education is a significant fact contributing to prospective teachers' emotional, spiritual and intellectual perfection. The findings suggest that the individual vocal expression has a significant impact on the future teachers' personal competence. It is important to underline that the individual vocal expression strongly influences creativity, self-confidence, emotionality and skills of achieving the goal. J. Lane (2004) states that correlation results indicated significant relationships between self-efficacy and self-esteem. Multiple regression results revealed that selfefficacy mediated the relationship between performance accomplishments and academic performance. According to B. Ford (2013), live performance is seen as a crucial part of being a professional musician and a performer's comfort in front of an audience often determines the success, failure or longevity of a career.

The scholars, who have thoroughly researched the subject of musical performance, refer to it as a skilled activity performed under intense pressure, thus often seen as a profound source of anxiety (Wells, 2012; Kirliauskienè, 2018; Kruglanski, 2000; Lane, 2004; Bostic, 2018; Li, 2014; Su, 2011; Tan, 2005; Susan, 2010; Li, 2009; Sun, 2003; Li, 2007). Therefore, the answer to the question how to encourage the development of students' self-confidence during performance to achieve good results is of utmost importance. The aim of the study is to reveal the peculiarities of promoting self-confidence of students as performers.

\section{Methodology}

The research was done applying several methods: scientific literature analysis, semi-structured interview, questionnaire survey, quantitative and qualitative analysis of collected data.

A specially designed questionnaire consisting of questions about the factors that have influence on development of self-confidence was used in the research. The questionnaire included 35 statements (factors) and the respondents were requested to respond to them indicating whether the factor was highly significant, 
significant or not highly significant. Revealing the students' attitude towards development of self-confidence on the stage, a semi-structured interview was employed. The interview consisted of open-ended questions about the peculiarities of developing self-confidence of a student as a performer. Openended questions encouraged students to provide more-detailed responses, which were not restricted by the specific variants for answers. The interview also focused on subjective opinion of participants in the interview. Different methods for processing the data were chosen seeking to better reveal factors that promote selfconfidence of prospective music teachers as performers.

The conducted empirical research included a questionnaire and an interview (Žydžiūnaitė \& Sabaliauskas, 2017; Kardelis, 2016; Langkos, 2014). Two hundred prospective music teachers participated in the questionnaire survey. There were 167 students from bachelor's degree programmes, 30 respondents from master's degree studies and 3 doctoral students. 10 students who study music education participated in the interview. All of 10 prospective music teachers reflected on the concept of self-confidence and improving self-confidence when performing on the stage. All the responses were grouped into categories and subcategories as well as supported by example quotes.

\section{Results and discussion}

The first part of the research employs a questionnaire, in which prospective music teachers responded to the questions related to their self-confidence and personal experiences while performing or preparing to perform on the stage.

Firstly, music education students answered the questions about the moments in their personal experience when they lacked self-confidence on the stage and what emotional reactions they went through. The following answers were provided: anxiety, low mood, trying to find ways to comfort themselves, overthinking, mind going blank, being unable to concentrate, complaining and blaming others. These results show that when music education students performed on the stage, most of them were able to control their emotions well: only 33 percent of the respondents felt constant anxiety, 13 percent had negative experiences, 26 percent could not stop thinking too much, 14 percent were feeling depressed and 23 percent were unable to focus. This proved that students were able to master their psychological state, to properly deal with the mistakes during the performance process and handle them calmly. Nevertheless, due to various reasons some students were not confident and had psychological issues, which lead to frequent fumbles and mistakes on the stage, as they could not deal with the aftermath well. Therefore, in the normal learning process, teachers should cultivate students' self-confidence, teamwork, and adaptability. 
Secondly, the students indicated the following factors which affect performers' self-confidence: self-regulation, physical function, physical and mental preparation, training status, experience accumulation, teacher's leadership, environmental and social factors. The results show that the majority of the respondents regard their experience as a performer (75 percent), their physical and psychological preparation (69 percent), and self-regulation (68 percent) as the most important factors that affect their confidence when performing. Thus, in order to promote self-confidence, they should be at the centre of attention. The results suggest that during the normal teaching process, teachers should teach students in accordance with their aptitude, the characteristics of each student, choose the repertoire suitable for the learners, and should not blindly choose the repertoire that is too difficult. Moreover, students should often be urged to practice carefully and follow suitable examples.

Furthermore, the participants were asked about the significance of certain factors to their self-confidence. Understanding of the lyrics content of musical pieces that the students were required to learn was among the popular answers with the majority of the students (46 percent) claiming that it played an important role in their self-confidence as performers. Similarly, the perception of the emotions of musical works was pointed out by the most of the respondents. The prospective music teachers also thought that their ability to comprehend the emotional content of the musical pieces they were learning in vocal music class was closely linked to them being confident when performing (47 percent). Interestingly, checking clothes, musical instruments, lights and venues before the show gathered mixed opinions as the majority of the students ( 45 percent) claimed that they did not have a clear opinion on whether this affected their selfconfidence during performances. However, a significant number of the respondents (41 percent) did state that this was an important factor, which seems reasonable, as making sure that everything is in the right place and working well might raise their self-confidence levels. The usage of the imagination on the stage during the performance was also chosen as important by many respondents (39\%), although the majority (46 percent) did not see the link between their confidence and the use of imagination. Nevertheless, it can be justified as a significant factor for students who find it helpful to imagine certain scenes in accordance to what they are singing and immersing themselves into the performance, consequently banishing the nerves and becoming more confident during the actual performance.

Moreover, using physical movements and body language during the performance was selected as yet another crucial factor by most of the respondents (48 percent) as well as the regulation of emotions during unsuccessful performances (47 percent). It is evident that the students' coping mechanisms during their performance are to use body language in order to appear - and in turn feel - more confident, and if all else fails, employing self-regulation techniques if 
it becomes evident that the performance is lacking. It is vital for the students to know that during the performance, there will be a variety of errors due to emotional fluctuations and learning how to properly deal with these mistakes in performance is a necessary skill for every performer. As for what happens after the performance, music education students list asking opinion from the teacher and peers after the performance and watching the video or recording of the performance summing up the advantages and disadvantages. An overwhelming number of respondents (52 percent and 54 percent respectively) claim that this helps: every performance is the accumulation of experience and the training of techniques, and after the performance, if the student communicates with the teacher more, she or he corrects the mistakes in time for the performance and improve the performance's quality. Listening to other students' advice, learners will be able to learn more from each other (Constantin, 2017).

Lastly, the respondents claim that being fully prepared for the performance in advance is very important (67 percent) in order to be a self-confident performer. Preparation includes mental preparation and physical preparation. Preliminary performance preparation includes: program selection, program practice, program costume, lighting design and more. Every performer should be fully prepared to stand confidently in the centre of the stage to bring the best visual and auditory sensations to the audience (Kirliauskienè, 2018; Livosky, Stevens, Holl, \& Surawski, 2012). The teacher should be well prepared for the music show as well. The preparation of the teacher includes memorizing music scores, warming up activities and self-regulating mental attitude. Teachers should be aware of how to prevent bigger errors during the performance as well as provide a rather relaxed playing mood which corresponds and matches with the current level of the performer.

The second part of the research is an interview with music education students, which was conducted to find out their opinions about self-confidence, the abilities of a successful performer, the reasons leading to the lack of selfconfidence, and suggestions as to how performers could improve in terms of being confident when performing on stage.

Firstly, Table 1 reveals the prospective music teachers' opinions on selfconfidence. The respondents were asked how they understand the concept of selfconfidence and were requested to define it.

Table 1 discloses three different definitions of confidence. Some interviewees think that self-confidence is a kind of external expression - whether you are not afraid to be yourself and make mistakes in order to learn. Some of the students think that self-confidence is a positive state - being psychologically well and feeling good about yourself, while others believe that self-confidence is a kind of self-awareness, which is the way one presents herself or himself to others and believes in her/his own abilities. 
SOCIETY. INTEGRATION. EDUCATION

Proceedings of the International Scientific Conference. Volume II, May $22^{\text {th }}-23^{\text {th }}, 2020.268-279$

Table 1 The Opinions of Interviewee on Self-Confidence

\begin{tabular}{|l|l|l|}
\hline Category & Sub-category & \multicolumn{1}{c|}{ Example of quotes } \\
\hline $\begin{array}{l}\text { Self- } \\
\text { confidence }\end{array}$ & $\begin{array}{l}\text { The external } \\
\text { expressions }\end{array}$ & $\begin{array}{l}\text { Confidence is an expression of one's ability or knowledge. } \\
\text { When you are sure about something, you will be fearless. } \\
\text { Being confident means not being afraid to show yourself, not } \\
\text { being afraid to make mistakes. }\end{array}$ \\
\hline & Positive state & $\begin{array}{l}\text { Is a kind of positive state, sometimes it makes me calm, but also } \\
\text { makes me excited. } \\
\text { Allows people to feel good. }\end{array}$ \\
\hline Self-awareness & $\begin{array}{l}\text { Believing in yourself, believing that you can do anything. } \\
\text { Being sure about the way you look and the way you dress. } \\
\text { Is an affirmation of one's own. }\end{array}$ \\
\hline
\end{tabular}

According to V. Kiik-Salupere (2013), confidence is a good emotion and it is necessary for success. Confidence is contextualized within domain-specific and person-specific self-views. Not everybody has a strong heart and will. Not everyone is a superman. Studying music is a lonely and hard road to follow. If students lack self-confidence, this can bring about many errors in further musical development. Therefore, students must live, learn and act with confidence in order to become confident performers.

In the next stage of the research, the different views of music education students about the reasons leading to their lack of confidence on stage are presented (Table 2).

Table 2 The Reasons Leading to the Lack of Confidence: Interviewees' Opinion

\begin{tabular}{|c|c|c|}
\hline Category & Sub-category & Example of quotes \\
\hline \multirow[t]{4}{*}{$\begin{array}{l}\text { Causes of } \\
\text { low self- } \\
\text { confidence }\end{array}$} & $\begin{array}{l}\text { Performing } \\
\text { environment }\end{array}$ & $\begin{array}{l}\text { Different environments, different audiences, and judges will } \\
\text { affect my confidence. } \\
\text { If the environment of a performance is unfamiliar to me, my } \\
\text { confidence will be very low. } \\
\text { If the instruments or equipment at the venue make me } \\
\text { uncomfortable, I get nervous. }\end{array}$ \\
\hline & $\begin{array}{l}\text { The physical and } \\
\text { psychological } \\
\text { preparation }\end{array}$ & $\begin{array}{l}\text { I feel nervous and lack confidence when my performance is } \\
\text { poorly prepared. } \\
\text { When I play while not feeling well, I don't have confidence. }\end{array}$ \\
\hline & Training status & $\begin{array}{l}\text { I have no confidence in myself when I perform without having } \\
\text { practiced enough. } \\
\text { I think I have no confidence at the times when I didn't practice } \\
\text { well. }\end{array}$ \\
\hline & Stage experience & $\begin{array}{l}\text { When I first performed on stage, I didn't have much } \\
\text { confidence. } \\
\text { If there is no rehearsal before the performance, I will feel } \\
\text { unconfident or nervous. } \\
\text { I think the main reason for my lack of confidence on stage is } \\
\text { that I have little stage experience. }\end{array}$ \\
\hline
\end{tabular}


Table 2 shows different causes for low self-confidence of music education students. Four main reasons why they felt nervous on stage were identified among the participants' responses: performing environment, the physical and psychological preparation, training status, and stage experience.

Different performance environments, stages, audience, musical instruments and such, affect the self-confidence of performers. If a performer is required to perform in an unknown environment, it will always cause some nervous reaction because they are unfamiliar with their surroundings. The same can be said about the audience - it is a known fact that some audiences can be very perceptive and supportive, while others can turn out to be passive and critical, thus affecting the performer in different ways. Physical factors also play a role: when the person's body feels uncomfortable, she or he may have no confidence to perform. However, according to the participants, the main reason for performers not to feel confident on stage is when they are not fully prepared. For example, if a singer performs on stage without memorizing the lyrics, it is simply impossible to be feeling very confident because they are bound to make mistakes and feel embarrassed. Similarly, lack of stage experience can result in insufficient selfconfidence. To conclude, when the reasons behind what makes music education students feel insecure or nervous on stage are clear, it becomes easier to find ways to overcome these problems and help them become confident performers on the stage (Ford, 2013; Cabedo-Mas \& Diaz-Gomez, 2013).

Table 3 below highlights the answers of the prospective teachers regarding the abilities of a self-confident performer.

Table 3 The Abilities of a Self-Confident Performer: Interviewees' Opinion

\begin{tabular}{|l|l|l|}
\hline Category & Sub-category & \multicolumn{1}{c|}{ Situations } \\
\hline $\begin{array}{l}\text { The } \\
\text { ability of a } \\
\text { confident } \\
\text { performer }\end{array}$ & $\begin{array}{l}\text { Ability } \\
\text { expression }\end{array}$ & $\begin{array}{l}\text { Lonfidence makes performers better on the stage. } \\
\text { A confident performer is able to better demonstrate what } \\
\text { they want to say, what they want to show to the audience } \\
\text { by their singing. }\end{array}$ \\
\cline { 2 - 3 } & $\begin{array}{l}\text { A confident performer is like the boss of a company who } \\
\text { can lead his employees. } \\
\text { If you are confident on the stage, you can influence other } \\
\text { performers to perform better. }\end{array}$ \\
\cline { 2 - 4 } & $\begin{array}{l}\text { Communication } \\
\text { ability }\end{array}$ & $\begin{array}{l}\text { audience } \text { how to keep eye contact, verbal contact with the } \\
\text { Confident performers are always able to interact with the } \\
\text { audience in appropriate situations. }\end{array}$ \\
\hline
\end{tabular}

The prospective music teachers were asked to describe what qualities make a confident performer, and their opinions can be divided into three categories: ability of expression, leadership and communication. Firstly, the respondents 
simply state that having confidence means that a performer is able to perform better on stage, or, in a more nuanced answer, they claim that confident performers are good at expressing emotions through their singing - when nerves and stagefright are not at the forefront of a performer's mind, she/he is able to focus on emotional expression and deliver a high-quality performance for the audience. Other students suggest that confidence is closely linked to leadership. If a performance is made up of many people, a confident performer takes the leading role, as it can inspire others to do their best by following their lead. Lastly, a very important characteristic of a confident performer is the ability to communicate. Since the main goal of any performer is to reach the audience and send them a meaningful message with their performance, according to the respondents, confidence allows an individual to keep eye contact and verbal contact with the listeners, and interact appropriately and in a meaningful way (Bostic, 2018; Corrigall, Schellenberg, \& Misura, 2013).

Lastly, the interviewees were asked to think of the means they tend to use to boost their self-confidence on the stage (Table 4).

Table 4 Increasing Self-Confidence on the Stage: Interviewees' Opinion

\begin{tabular}{|l|l|l|}
\hline Category & Sub-category & \multicolumn{1}{c|}{ Situations } \\
\hline $\begin{array}{l}\text { Increasing } \\
\text { confidence }\end{array}$ & $\begin{array}{l}\text { Learn more } \\
\text { about music } \\
\text { knowledge and } \\
\text { music skills }\end{array}$ & $\begin{array}{l}\text { If I feel nervous, I think the reason is I did not exercise } \\
\text { enough on my instrument, so the logical solution is to } \\
\text { practice more. } \\
\text { Ido not have enough knowledge about performing; maybe } \\
\text { learning more would help me become more confident on } \\
\text { stage. } \\
\text { Gaining more knowledge and skills is the best way to } \\
\text { improve your confidence on the stage. }\end{array}$ \\
\cline { 2 - 4 } & Practice harder & $\begin{array}{l}\text { Music is difficult, if I want to be successful on the stage, I } \\
\text { need more time and practice. } \\
\text { You need to practice every day, same as you eat every day. } \\
\text { Constant practice is constant growth in self-confidence. }\end{array}$ \\
\cline { 2 - 4 } & Self-suggestion & $\begin{array}{l}\text { Iused to say to myself before a show, "You can do it! You're } \\
\text { the best! } \\
\text { Fake it till you make it. }\end{array}$ \\
\hline
\end{tabular}

Table 4 illustrates the different ways that according to the interviewed students would help to boost their self-confidence when performing on stage.

First, according to the respondents, it is important to gain more music knowledge and exercise music skills, because the more the students understand the subject and the higher their skill levels are, the more confident they should become while performing on stage. Secondly, the interviewed prospective music teachers stress that practicing hard is beneficial in order to increase confidence, 
since, as previously indicated, many issues with self-confidence arise from not being fully prepared for the performance. The students are aware that hard practice can help them become more confident when performing because this is the most effective way of ensuring absence of mistakes on stage. Lastly, students think that in order to be more confident on stage, it is necessary to employ selfsuggestion - believing in oneself and practicing positive thinking could override harsh self-critique, judgement from oneself or others and help immensely in boosting self-confidence during the actual performances on stage.

\section{Conclusions}

Self-confidence is a key factor influencing stage performance. It is one of the main guarantees of a successful performance. The most important factor in creating a positive state of mind on stage is self-confidence - excellent technical and artistic repertoire preparation, stage experience, musical abilities and skills, personal qualities and emotional control, as well as positive attitude are vital in order to achieve that proper state of mind.

The results of the research suggest that prospective music teachers feel very anxious when they lack confidence: some students have low mood when they lack self-confidence, their brain stops thinking, they feel depressed, are unable to concentrate, hesitate of what is right and wrong, complain and blame others. Therefore, in the daily learning process, teachers should cultivate students' selfconfidence, teamwork, and adaptability. Moreover, according to the responses obtained using the questionnaire, there are different factors affecting the confidence of performers: self-regulation, physical function, physical and psychological preparation, training status, experience accumulation, teacher's leadership, environment and social support. Being aware of these factors, it is easier to enable music education students to enhance their self-confidence.

The interview revealed the factors influencing self-confidence of students as performers, and they are as follows: external expressions, positive state, selfawareness, ability of expression, leadership and communication abilities. The reasons leading to the lack of self-confidence are as follows: performing environment, physical and psychological preparation, amount of practice done before the performance and stage experience. Moreover, the research disclosed the students' suggestions on how to increase self-confidence on stage. Students should accumulate more music knowledge and improve their music skills. They should also allocate more time to efficient practicing. 
SOCIETY. INTEGRATION. EDUCATION

Proceedings of the International Scientific Conference. Volume II, May $22^{\text {th }}-23^{\text {th }}, 2020.268-279$

\section{References}

Bostic, D. (2018). Confidence in the Face of Challenges. FBI Law Enforcement Bulletin, 7-10.

Cabedo-Mas, A., \& Diaz-Gomez M. (2013). Positive musical experience in education: music as a social praxis. Music Education research, 4, 455-470.

Constantin, F. (2017). Mental Training For Musicians - Excellence In Performance. Bulletin of the Transylvania University of Brasov, 8, 33-44.

Corrigall, K.A., Schellenberg, G., \& Misura, M.N. (2013). Music training, cognition, and personality. Frontiers of psychology, 4, 1-10.

Ford, B. (2013). Approaches to performance: A comparison of music and acting students' concepts of preparation, audience and performance. Music Performance Research, 152169.

Kardelis, K. (2016). Moksliniu tyrimu metodologija ir metodai [Methodology and Methods of Scientific Research]. Vilnius: Mokslo enciklopediju leidybos centras.

Kiik-Salupere, V. (2013). Factors Influencing Singing Students' Confidence to Sing. The Changing Face of Music \& Art Education, 89-109.

Kirkpatrick, J.M., \& Mortimer, J.T. (2002). Career choice and development from a sociological perspective. San Francisco: Jossey-Bass a Wiley Company.

Kirliauskienè, R. (2018). Factors Affecting The State Of Being In Front Of The Audience. International Multidisciplinary Scientific Conferences on Social Sciences \& Arts SGEM, 89-99.

Kruglanski, A. (2000). Locomotion and assessment as distinct self-regulatory imperatives. Finland: Personality and Social Psychology, 793-815.

Lane, J. (2004). Self-Efficacy, Self-Esteem and Their Impact On Academic Performance. Social Behavior \& Personality: an international journal, 247-256.

Langkos, S. (2014). Research Methodology. Derby: University of Derby.

$\mathrm{Li}, \mathrm{C}$. (2007). Stage performance and cultivation of psychological quality. Music world, 46-50.

$\mathrm{Li}, \mathrm{H}$. (2009). How to cultivate students' self-confidence in singing in music teaching. Career, $72-76$.

Li, X. (2014). Good Psychological Quality and Mentality Training in Piano. China: Playing. Social Science Theory, 10, 189-190.

Livosky, M., Stevens, B.L., Holl, R., \& Surawski, M. (2012). Personality and Music Preferences in College Students and Young Children. Psychology journal, 1, 13-25.

Paliaukienè, V. (2018). Music performance anxiety among students of the academy in Lithuania. Music Education Research, 390-397.

Spielman, H. (2009). Conquering Performance Anxiety From Inside Out. The Flute Magazine, 29-34.

Su, D. (2011). Youth self-regulatory learning development characteristics and mechanism of brain research. China: Capital Normal University, 4-11.

Sun, Y. (2003). Effective Strategies of Cultivating Self-regulated Learning. Chongqing Vocational and Technical Institute, 12, 77-79.

Susan, H. (2010). The power of music: Its impact on the intellectual, social and personal development of children and young people. International Journal of Music Education, 269-289.

Tan, X. (2005). Self-regulation and Its Research Outline. China: School of Management Southwest China Normal University. Journal of Mianyang Normal University, 24, 67-70. 
Wells, R. (2012). Matter Over Mind: A Randomised-Controlled Trial of Single-Session Biofeedback Training on Performance Anxiety and Heart Rate Variability in Musicians. Plos One, 1-11.

Žydžiūnaitė, V., \& Sabaliauskas, S. (2017). Kokybiniai tyrimai: principai ir metodai [Qualitative Research: Principles and Methodology]. Vilnius: Vaga. 